\title{
The Process of English Language Teaching in the 2013 Curriculum
}

\author{
Arif Bulan ${ }^{1}$, Maman Suryaman ${ }^{2}$, Mardiah $^{3}$ \\ STKIP Yapis Dompu ${ }^{1 \& 3}$, Indonesia; Universitas Negeri Yogyakarta ${ }^{2}$, Indonesia \\ Correspondence: Arif Bulan, STKIP Yapis Dompu; Indonesia. e-mail:arifbulan1 @gmail.com \\ Submitted: April 02, 2020 \\ Revised: April 20, $2020 \quad$ Accepted: April 24, 2020 \\ DOI: $10.29408 /$ veles.v4i1.2007 \\ URL: http://dx.doi.org/10.29408/veles.v4i1.2007
}

\begin{abstract}
This study was motivated by the replacement and implementation of the 2013 curriculum in Indonesia. This study aimed to find out how the process of English language teaching in 2013 curriculum, what are the teacher's constraints on English language teaching process, and the efforts by the teachers. This study was a qualitative research. The samples of this study were six teachers from six state high schools in Sleman regency. Data collection in this study used observation, document analysis and interview. Data analysis technique used qualitative descriptive technique. The results of the study indicated that the process of English language teaching using the 2013 curriculum was very good. The process of language teaching had implemented through three steps, starting with the pre-activity, core activity, and post activity. The process of English teaching was based on process standard in 2013 curriculum by using a scientific approach as one approach that encourages students to learn actively in developing attitude, knowledge and skill. The obstacles faced by teachers in the process of learning English include: less of time, need to adapt to the scientific approach, and lack of 2013 curriculum handbooks. the efforts done by teachers were consultation with senior teacher and instructor of curriculum 2013, routine discussion in MGMP forum, and searching sources of learning from various sources. Conclusion, the learning process in the 2013 curriculum is carried out based on the standard learning process by using a scientific approach that encourages students to learn actively in developing attitude, knowledge and skill.
\end{abstract}

Keywords: Teaching process, English language teaching, 2013 curriculum

\section{Introduction}

The beginning of the 2013 curriculum development discourse has actually reaped the pros and cons of various parties, both teachers and educational experts. Hamalik (2009) said, the problems in the curriculum are related to the fields of coverage, relevance, balance, integration, sequences, sustainability, articulation, and transferability. Meanwhile, Mulyasa (2014) questioned the fate of the 2013 curriculum if its development ran aground in the middle of the 
road. Based on the contradiction, the government through the Ministry of Education and Culture assured that the 2013 curriculum had the urgency to be developed. The development of the 2013 curriculum is deemed necessary because of the various challenges faced by the nation and the world of education, these challenges are internal challenges, external challenges, improvement of mind set, strengthening curriculum governance, and deepening and expanding material. Internal challenges are related to meeting national education standards and the development of Indonesia's productive age population. While external challenges are related to future challenges such as globalization, technological advances, future competencies, public perceptions, the development of science and pedagogy, and the negative phenomenon of students.

In Indonesia, at least, there have been several changes to the curriculum. The curriculum includes, Curriculum 1947, Curriculum 1952, Curriculum 1964, Curriculum 1968, Curriculum 1975, Curriculum 1984, Curriculum 1994, KBK Curriculum, Education Unit Level Curriculum, and the last is the 2013 Curriculum refinement because of the demands of the times. Implementation of the curriculum is a process of applying curriculum plans in the form of learning (Beauchamp, 1975; Fullan, 2007; Hamalik, 2009; Suryaman, 2012). The application of the curriculum relates to what must be taught at school. Something taught in school is a general guideline or commonly known as an explicit curriculum that requires teacher interpretation. Therefore, as revealed by Pugach (2006) the implementation of the curriculum is closely related to the taught curriculum. Taught curriculum can be interpreted as a program implemented by the teacher in the classroom. In addition, Glatthorn, Boschee, and Whitehead (2012) disclosed what is conveyed in relation to the concepts and plans of the curriculum as documents in general that need to be applied in class.

Majid (2014) emphasized four things that need to be considered in curriculum implementation. First, implementation can be interpreted as actualizing plans or curriculum concepts. Second, curriculum implementation can be interpreted as a learning process. Third, curriculum implementation can be interpreted as the realization of ideas, values and curriculum concepts. Fourth, curriculum implementation can be interpreted as a process of changing student behaviour. In this context, what needs to be emphasized in this discussion is the curriculum as a learning process. This is the same as what was mentioned by Pugach (2006) that curriculum is what should be taught to students. But the implementation of the curriculum is not just the implementation of the curriculum, but a complex process of educational change involving many parties in schools, such as changes in mind set, individual feelings, groups and school culture (Brady \& Kennedy, 2010).

A good learning process must begin with a good planning of learning (Bulan \& Suryaman, 2018). Learning is an activity or process of interaction that occurs in the classroom between teachers and students, where the interaction process aims to produce appropriate competencies and has been determined by the world of education (Bahri \& Zain, 2010; McGill \& Brockbank, 2004; Mulyasa, 2014; Sudjana, 2010). The learning process in the classroom can be seen from two perspectives, namely the teacher's point of view and the students' point of view. Abidin (2016) classified the learning process from the teacher's perspective as a series of activities 
carried out by the teacher so that students learn. While from the students' point of view, learning is a process that contains a set of activities that students carry out to achieve learning goals. Therefore, the learning process can be understood as an activity carried out by teachers and students in the context of giving reinforcement, direction and motivation so that students achieve certain learning outcomes. In addition, what is an important point in the learning process must focus on students (Choy, Sedhu, Liew, et al: 2015).

Bonnor and Caro (2012) revealed that good learning must focus on the level of intellectual quality that produces an in-depth understanding of important concepts, skills, and ideas. Students must be able to build knowledge by developing high-level thinking and communication. Furthermore, good learning requires an environment that supports this learning. This environment encourages participation and also encourages positive relationships between students. In addition, learning also becomes meaningful and important for students if it accommodates the needs, experiences and desires of students.

Kidd and Czerniwski (2010) revealed that "good teaching is based on through planning". The learning process in the class depends on learning planning. In addition, the learning process also needs to be considered systematic activities carried out by the teacher. These systematic activities include initial activities, core activities, and final activities. The initial activity was carried out to conduct a kind of introduction to the topic of learning, core activities carried out to convey the material and the interaction process, and the final activity was a reflection and evaluation of students' understanding of the topic being taught. Mulyasa (2014) added that when the initial activity was the stage of familiarity, where the teacher delivered the opening greetings to introduce learning material. After that, enter at the core stage where this activity includes the delivery of information, delivery of material and finally the assignment.

The 2013 curriculum learning process emphasizes the scientific approach and students center, where students are the center of learning. In Sleman Regency High School, it was not yet known how the implementation of the 2013 curriculum in the English learning process. Meanwhile, it is interesting to study deeply. Based on the explanation above, this study aims to answer the research questions: how is the 2013 curriculum implemented in the English learning process, what are the teacher's constraints in English learning process, and what are the teacher's efforts of the English teachers in facing obstacles in English learning process at senior high schools?

\section{Method}

This study uses a qualitative approach. In this study, data collection was carried out by observation, document analysis, and interviews. Observations in this study put researchers as non-participatory observers. Non-participatory observation is that researchers mingle with students in class and follow the learning process. Therefore, the instrument used in observation uses a checklist. The observation sheet in this study is a note to record the results of observations or observations made by researchers during the learning process takes place in the classroom. The observation sheet is filled by the researcher himself by looking at and observing the 
conditions that are in accordance with the conditions that occur during the learning process, meaning that the researcher is present in open observations where the researcher mingles and follows the learning process. The interview guide in this study is in the form of structured question items, meaning that the questions in the interview follow the guidelines prepared by the researcher to obtain data on the implementation of the 2013 curriculum on English subjects. Meanwhile, document analysis was carried out in this study through a checklist to see the completeness of 2013 curriculum documents.

\subsection{Participants}

Participants in this study were 6 teachers selected by purposive sampling. This research was conducted in 6 public high schools that have implemented the 2013 curriculum in Sleman Regency. The 6 schools were taken based on the acquisition of the results of the national exam in 2018, there were schools that received low, middle and high national exam results.

\subsection{Data Collection}

\subsubsection{Instrument of Collecting Data}

Research instruments are tools that can be used to collect and obtain data and information. The instruments used in this study were observation sheets, structured interview guidelines and document analysis. The observation sheet in this study is in the form of notes to record the results of observations made by researchers during the learning process in the classroom. The observation sheet is filled in by the researcher himself by looking at and observing conditions that are in accordance with the conditions that occur during the learning process, meaning that the researcher is present in an open observation where the researcher mingles and follows the learning process. Interview guidelines in this study are structured question items, meaning that the questions in the interview follow the guidelines that have been prepared by researchers to get data from the implementation of the 2013 curriculum in English subjects. Meanwhile, document analysis was carried out in this study through a suitable list (checklist) to see the completeness of 2013 curriculum documents.

\subsubsection{Techniques for Collecting Data}

Data collection techniques in this study using non-test techniques such as interviews, observation, and document analysis. Observation technique is carried out to get data about the learning process. Observations in this study put researchers as non-participatory observers. Nonparticipatory observation, that is, researchers mingle with students in class and follow the learning process. Therefore, the instrument used in observation uses a checklist. The document analysis technique is used to obtain data supporting the implementation of the 2013 curriculum in English subjects. Interview techniques are used to obtain more detailed and in-depth information from respondents. The interview was conducted by structured interview. In a structured interview questions are asked to the respondent in this case the English teacher, each key respondent is given the same question. The instruments used in the interview use structured 
interview guidelines, meaning that the questions raised in the interview process with respondents have been prepared in advance.

\subsection{Data Analysis}

The data analysis uses an analysis model from Miles, Huberman, and Saldana (2014) starting from "data collection, condensation data, data display, and conclusion." The qualitative data analysis phase includes data collection, data condensation, data presentation and conclusion drawing. Data collection is done through document analysis and interviews. The results of the interview data are then narrated. After the data is collected, data condensation is carried out or selected, focused, simplified, abstracted and transformed the data that appears in its full form from written field notes, interview copies, documents and other empirical material (Miles, Huberman, \& Saldana, 2014). After condensation is done, then the data display will be carried out. In this study the presentation of data was carried out descriptively and used the data presentation table. After the data is presented then the final process is carried out, taken the conclusion.

\section{Results and Discussion}

Three main indicators of English language teaching and learning process of 2013 curriculum, namely preliminary activities, core activities and closing activities. The indicators in the preliminary activities include: preparing students psychologically and physically, conveying the scope of the material and explaining the description of activities, motivating contextual student learning according to the benefits and application of learning material, asking questions that relate previous knowledge to the material to be studied, and convey series of learning activities. While core activities include: mastery of learning material, application of learning strategies, application of scientific approaches, utilization of learning resources, use of media in learning, implementation of authentic assessment, involvement of students in learning, use of correct and appropriate language in learning. While the closing activities include: facilitating students to conclude learning material, provide feedback on the process and results of learning, follow up in the form of giving individual or group assignments, and informing the planning of learning activities for the next meeting.

Table 1. Analysis of the learning process in 2013 curriculum

\begin{tabular}{llll}
\hline \multirow{2}{*}{ Criteria } & Score & \multicolumn{2}{l}{ Learning Process } \\
\cline { 3 - 4 } & & Number of teacher & Percentage \\
\hline Very good & $\mathrm{ST} \geq \mathrm{X} \geq \mathrm{Mi}+1,5 \mathrm{SDi}$ & 2 & $33.33 \%$ \\
Good & $\mathrm{Mi}+1,5 \mathrm{SDi}>\mathrm{X} \geq \mathrm{Mi}$ & 4 & $66.67 \%$ \\
Average & $\mathrm{Mi}>\mathrm{X} \geq \mathrm{Mi}-1,5 \mathrm{SDi}$ & 0 & $0 \%$ \\
Bad & $\mathrm{Mi}-1,5 \mathrm{SDi}>\mathrm{X} \geq \mathrm{SR}$ & 0 & $0 \%$ \\
Total & & $\mathbf{6}$ & $\mathbf{1 0 0 \%}$ \\
\hline
\end{tabular}

Data on the learning process at the State Senior High Schools in Sleman Regency as seen in the table above was measured using 33 observation sheet learning process statements using a modified scale with a score of 1 for statement items that were not implemented and 2 for items 
statement carried out. The learning process observation sheet is used to observe the 6 respondents who have been selected using the purposive sampling method from 34 existing respondents. The data of the six teacher respondents was analyzed using the help of Microsoft Excel software. The data above shows that as many as $33.33 \%$ of teachers have implemented the 2013 curriculum in the learning process very well, while $66.67 \%$ of teachers have implemented the 2013 curriculum in the learning process well. Based on data from the observation process of the learning process, the percentage of the implementation of the 2013 curriculum in the learning process was an average of 75\%. This shows that the implementation of the 2013 curriculum on English subjects in the learning process at the State High School in Sleman Regency was in a very good category.

The process of learning English in the classroom is a process of implementing plans for implementing learning that have been made by teachers (Bahri \& Zain, 2010). The learning process in the classroom includes three main activities, namely the initial activity, the core activity, and the final activity or closing. These three main activities must be in accordance with the Process Standards determined by the government through the regulation of minister of education and culture number 22 year 2016 with the consequence that the learning process in the education unit is held interactively, inspiring, fun, challenging, motivating students to actively participate, and providing sufficient space for initiatives, creativity, and independence in accordance with the talents, interests and physical and psychological development of students. The steps of learning activities must be characterized by a scientific approach and the use of learning models that are in accordance with English learning such as direct, cooperative, contextual learning, problems based learning and project-based learning that are implemented in an integrated manner in attaining competency attitude, knowledge, and skill.

The process of learning English in the 2013 curriculum conducted by teachers in the classroom must be in accordance with the standards of processes such as preliminary activities, core activities, and closing activities. As stated by Sudjana (2010) the learning process is a process that is arranged in such a way according to certain steps so that the implementation of learning reaches the expected results. Preliminary activities include activities in the form of appreciation and motivation that can make students ready psychologically and physically, can attract the attention of students to learn and more importantly, the teacher conveys competencies and plans for learning activities to students so that they have motivation that high to follow the learning process sequence. The core activities are carried out with a scientific approach that includes observing, asking, trying, reasoning, presenting, and creating activities combined with learning models that are in accordance with scientific approaches such as discovery learning, inquiry learning, project based learning, the use of media and learning resources that are suitable for learning objectives, as well as an assessment of attitudes, knowledge, and skills (authentic) during the learning process. The closing activity is an activity carried out by the teacher to determine the extent to which the learning process has given effect in the form of increasing knowledge and skills of students by facilitating students to conclude learning outcomes, provide feedback on learning processes and outcomes, and provide follow-up and next lesson plan. 
Based on the observation process of the learning process by researcher, it is known that the process of learning English includes a very good category, meaning that in general English teachers have implemented three main activities, namely preliminary activities, core activities and closing activities as mandated by the government. The preliminary activities of English learning carried out by the teacher can be in the form of apperception and motivation, as well as the delivery of goals and plans for learning activities. Based on the analysis of data per indicator, the indicators of the preliminary activities in the learning process included good categories, but in the statement items 6 most of the teachers did not submit plans for learning activities in the preliminary activities. Submission of plans for learning activities from the beginning can make students know from the start what they will do during the learning process and can motivate students to learn the activities that have been delivered by the teachers.

The core activity in learning English in the 2013 curriculum did not only emphasize the scientific approach, based on the results of interviews, the teacher reveals that the scientific approach is not the only approach that must be used in the learning process. In addition to the scientific approach, the core activities also see how teachers master learning material, apply learning strategies, utilize learning resources and learning media, implement authentic assessments, engage students in learning, and use correct and appropriate language in the learning process. Based on observations it is known that teachers in learning activities are included in the very good category, meaning that the teacher is able to facilitate students in acquiring knowledge, skills and attitude contained in the learning objectives. This is supported by the results of interviews that the average teacher has twice participated in 2013 curriculum training and socialization, besides the MGMP and the school also facilitated training to increase teacher knowledge in the 2013 curriculum implementation. The closing activity of the 2013 English learning curriculum was in a good category, but there are two teachers who do not carry out closing activities at all, this is because the teacher takes too long to discuss the material in the core activities so that time is not enough. In addition, based on interview data, two hours of weekly English lessons are not enough for teachers because of the wide range of material students must learn.

In the implementation of the 2013 curriculum in the process of learning English the High School of the State High School must have encountered several obstacles. Constraints in the learning process experienced by teachers include a lack of hours of English language learning which was only 2 hours a week. This greatly affects the depth and depth of the basic competencies that must be taught by the teacher in the learning process. Meanwhile, another obstacle faced by teachers is that teachers have difficulty applying the scientific approach because not all materials can use $5 \mathrm{M}$, this is due to the lack of learning resources to support them to carry out $5 \mathrm{M}$ activities. In addition, another obstacle is the lack of a 2013 curriculum print book for students, not all students get printed books, resulting in the learning process using books prepared by the teacher himself. According to the research of Katuuk (2014) the factors of facilities and infrastructure such as textbooks have an effect on the implementation of the 2013 
curriculum. Therefore, innovative teachers are needed who can determine the type, form, and content of the books in accordance with the 2013 curriculum.

The efforts made by the teacher to overcome the above constraints include: consulting with the 2013 curriculum and senior instructor teachers, having regular discussions in the MGMP forum, combining relevant material discussions, using various strategies and active learning approaches, looking for learning resources from various sources, and use the observation sheet and ask for the opinions of other teachers.

\section{Conclusion}

The process of learning English that has been carried out by teachers at Government High Schools in Sleman Regency is very well implemented. The process of learning English has gone through three stages of learning activities starting from the introduction, core, and closing activities. The learning process in the 2013 curriculum is carried out based on the standard learning process by using a scientific approach as an approach that encourages students to learn actively in developing attitude, knowledge and skill.

\section{References}

Abidin, Y. (2016). Desain sistem pembelajaran dalam konteks kurikulum 2013 (cet. Ketiga). Bandung: Reflika Aditama.

Bahri, S.D. \& Zain, A. (2010). Strategi belajar mengajar. Jakarta: Rineka Cipta.

Beauchamp, A.G. (1975). Curriculum theory. Illinois: The Kagg Press.

Bonnor, C. \& Caro, J. (2012). What makes a good school. Australia: New South Publishing.

Brady, L. \& Kennedy, F. (2010). Curriculum construction (4 ${ }^{\text {th }}$ ed.). Australia: Pearson.

Bulan, A., \& Suryaman, M. (2018). the Implementation of English Lesson Plan of Curriculum 2013 At Senior High School in Sleman Regency, Indonesia. JIIP) Jurnal Ilmiah Ilmu Pendidikan, 1(3), 129-133. Retrieved from http://jiip.stkipyapisdompu.ac.id

Choy, S.T., Sedhu, D.S., Liew, Y.L., Lee, M.Y., Malanee, A., \& Anuar, N. (2015). Influence of culture on students' awareness of howand why they learn. Malaysian Journal of learning and Instruction, 12, 49-67.

Fullan, M. (2007). The new meaning of educational change. New York: Teacher Collage Press.

Glatthorn, A.A., Boschee, F., Whitehead, B.M., et al. (2012). Curriculum Leadership: Strategies for Development and Implementation ( $\left.3^{\text {rd }} \mathrm{ed}\right)$. London: SAGE Publication.

Hamalik, O. (2009). Dasar-dasar pengembangan kurikulum (cet. Ketiga). Bandung: PT Remaja Rosdakarya.

Katuuk, D.A. (2014). Manajemen implementasi kurikulum: strategi penguatan implementasi kurikulum 2013. Jurnal Cakrawala Pendidikan, 16 (1), 13-26.

Kemendikbud. (2014). Peraturan menteri pendidikan dan kebudayaan Nomor 68 Tahun 2014 tentang peran guru dalam implementasi kurikulum 2013. Jakarta: Kemendikbud.

Kidd, W. \& Czerniawski, G. (2010). Successful teaching 14-19: theory, practice and reflection. London: SAGE Publication Inc. Miller, M.D., Linn, R.L., \& Grondlund, N.E. (2009). 
Measurement and assessment in teaching $\left(10^{\text {th }}\right.$ ed). Upper Saddle River New Jersey: Pearson Education Inc.

Majid, A. (2014). Implementasi kurikulum 2013: Kajian teoretis dan praktis. Bandung: Interes. Mardapi, D. (2012). Pengukuran, penilaian \& evaluasi pendidikan. Yogyakarta: Nuha Litera.

McGill, I. \& Brockbank, A. (2004). The action learning handbook. London: Routledge Falmer.

Miles, B.M., Huberman, A.M., \& Saldana, J. (2014). Qualitative data analysis methods sourcebook $\left(3^{\text {rd }} e d\right)$. New York: SAGE Publications, Inc.

Mulyasa, E. (2014). Pengembangan dan implementasi kurikulum 2013 (Cet. Keempat). Bandung: PT Remaja Rosdakarya Offset.

Pugach, M.C. (2006). Because teaching matters. New York: John Wiley and Sons, Inc.

Retnawati, H. (2015). Validitas, reliabilitas dan karakteristik butir: Panduan untuk peneliti, mahasiswa, dan psikometri. Yogyakarta: Parama Publishing.

Suryaman, M. (2012). Metodologi pembelajaran bahasa. Yogyakarta: UNY Press.

Sudjana, N. (2010). Dasar-dasar proses belajar mengajar. Bandung: Sinar Baru Algesindo. 